Egyptian Journal of Rabbit Science, 31(1): 57- 71 (2021)

\title{
EFFECT OF DIETS CONTAINING SEA-GRASS (Cymodocea nodosa) AND TARO HAULMS (Colocasia esculenta) ON REPRODUCTIVE PERFORMANCE OF NEW-ZEALAND FEMALE RABBITS UNDER NORTH SINAI CONDITIONS
}

\author{
M. M. Shetaewi*; Mousa, M. R. M.; Bakr, E. O. A.; Walaa, A. A. S. \\ Department of Animal and Poultry Production, College of Environmental \\ Agricultural Sciences, Arish University, Egypt. \\ * e. mail: mosad.shetaewi@gmail.com
}

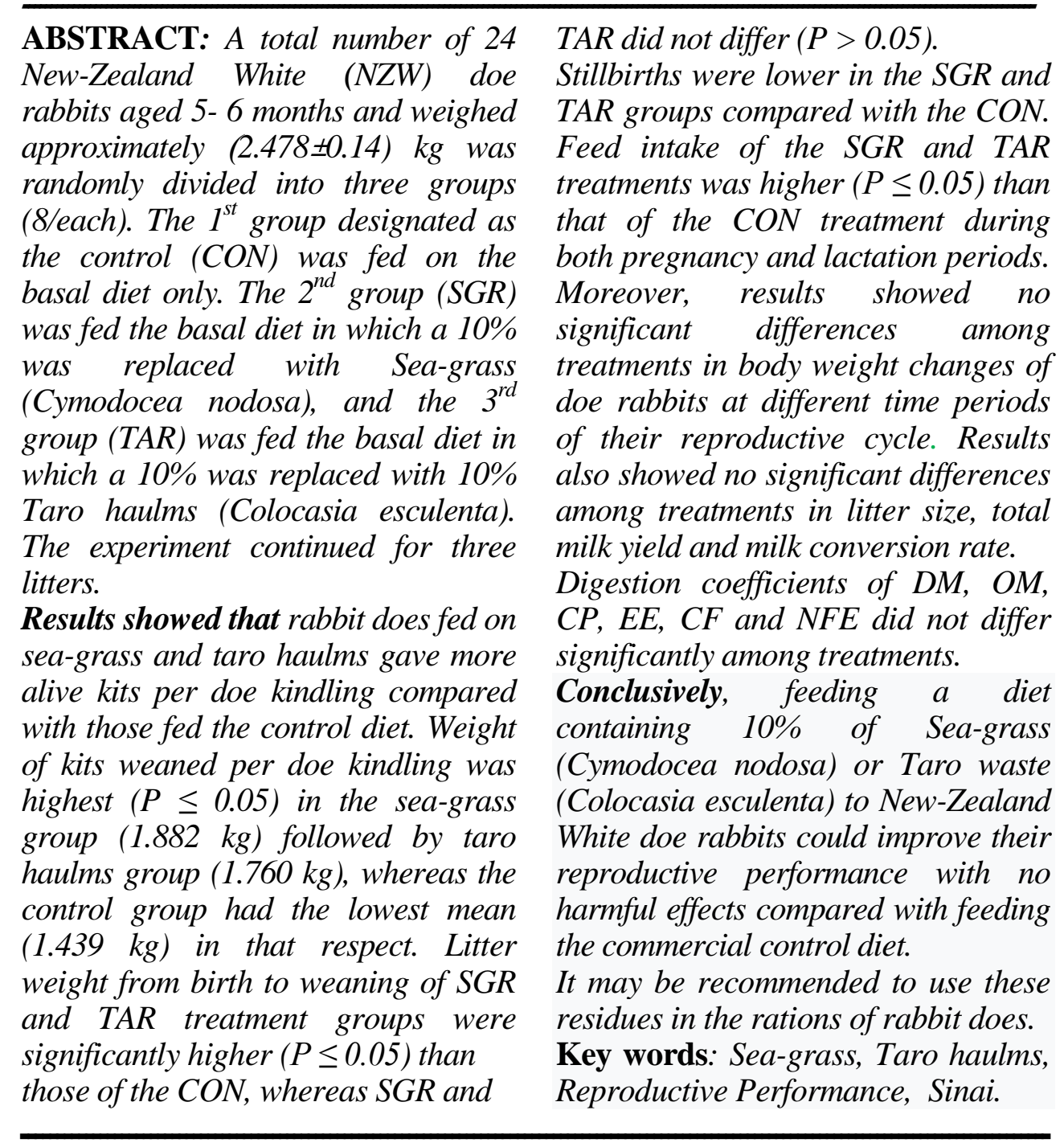




\section{INTRODUCTION}

Compared to other larger domestic species, rabbits have many advantages including high reproductive rates, rapid growth rates, use of noncompetitive feeds and simple housing requirements. Due to the high cost of feeding rabbits on traditional feedstuffs, it could be a wise practice to use some untraditional feeds with reasonable nutritional value to reduce the costs of their nutrition.

Sea-grass contains high carbohydrates, proteins, fiber, vitamins and minerals (Abdel-Hady et al., 2007). It contains also high amounts of vitamin A, $\mathrm{C}$ and $\mathrm{E}$ in the rhizome/root (Jeevitha et al., 2013). Moreover, Kolsi et al., (2018) reported that sea-grasses could be used as natural antioxidants. Vegetable haulms (Taro haulms) are unconventional feed resources and rich sources of nutrients. They can be used in feeding livestock after drying without affecting nutrient utilization, palatability, health or performance of animals (Wadhwa and Bakshi, 2013).

Therefore, this study was carried out to evaluate effects of Sea-grass (Cymodocea nodosa) and Taro haulms (Colocasia esculenta) on reproductive performance of female NZW rabbits under North Sinai conditions.

\section{MATERIALS AND METHODS}

The present study was carried out at the Rabbitry Farm, Department of Animal and Poultry Production, Faculty of Environmental Agricultural Sciences, Arish University, North Sinai, Egypt, during the period from February to June 2019. The objective of this study was to utilize some untraditional feeds such as sea grass and taro haulms available with low prices to evaluate their effects on reproductive performance of NZW rabbit does under North-Sinai conditions.

\section{Plant collection and preparation of the experimental diets:}

Sea-grass (Cymodocea nodosa) is found in reasonable quantities along the coasts of the Egyption Mediterranean Sea. It was collected from the area around Bardawil Lake in North Sinai, Egypt and included all parts of the plant. Colocasia esculenta is found in abundant quantities in Menofiya Governorate. Dried (C. esculenta) which included leaves and petioles (false stems) was provided by Menofiya Governorate. The Sea-grass and Taro haulms were sundried until their content of moisture roughly reached $10 \%$, then grounded as powder and samples were taken in plastic bags for chemical analysis.

\section{Experimental animals, management and treatments:}

A total number of 24 NZW doe rabbits aged 5-6 months and weighed approximately $(2.478 \pm 0.138 \mathrm{~kg})$ was randomly divided into three groups (8/each). The $1^{\text {st }}$ group designated as the control $(\mathrm{CON})$ was fed on the basal 


\section{EFFECT OF DIETS CONTAINING SEA-GRASS \& TARO HAULMS ON RABBITS 59}

diet only. The $2^{\text {nd }}$ group (SGR) was fed the basal diet in which a $10 \%$ was replaced with sea-grass (Cymodocea nodosa), and the $3^{\text {rd }}$ group (TAR) was fed the basal diet in which a $10 \%$ was replaced with taro haulms (Colocasia esculenta). All diets were offered to animals in a pelleted form. This experiment aimed at evaluating the effects of these experimental diets on reproductive performance of NZW rabbit does and survival of their kits from birth to weaning. The experiment continued for three litters. All rabbits used in these experiments were healthy and clinically free of external and internal parasites. These animals were raised in efficient hygienic control flat deck batteries with universal specification and accommodated with feeders and drinkers for providing animals with feed pellets and water according to their assigned treatments. The rabbits were housed in a well-ventilated galvanized wire maternity cages. The rabbit does were housed in individual cages of $(40 \mathrm{x}$ $55 \times 60 \mathrm{~cm}$ ) with a height of $100 \mathrm{~cm}$ from the concrete floor. Each cage was provided with a natal box for kindling and nursing the kits during the suckling period, and was provided with feeders and automatic nipple drinkers. Batteries were arranged in rows in the rearing house in which windows were available for natural ventilation and lighting and provided also with electric fans. A cycle of 16h light: $8 \mathrm{~h}$ dark was applied using controlled artificial lightening throughout the experimental period. Diets were offered to rabbits ad libitum and fresh water was available all the time. All the experimental diets were formulated to fulfill the nutrient requirements for rabbits according to (NRC, 1977). The ingredients of the experimental diets used in the present study is shown in (Table 1). Moreover, the chemical composition of SGR (C. nodosa) and TAR (C. esculanta) used in this study and chemical analysis of experimental diets are shown in (Table 2).

\section{Reproductive traits of doe rabbits and viability of their kits:}

New-Zealand White rabbit does were mated naturally with healthy and examined bucks of the same breed. Mating was done by transferring the female to the male cage and returned back to its own cage after copulation. Pregnancy test was done by palpation at d 12 post-mating (Shetaewi et al., 2000). At kindling time, litters were checked and recorded for their size and weight. Afterwards, litters in the nest were checked each morning to remove the dead offspring. Young rabbits were weaned 28 days after kindling and transferred to other wire cages in groups of two each.

\section{Milk yield of doe rabbits:}

Milk yield of doe rabbits were measured every week beginning at $\mathrm{d} 7$ post-kindling and continued until d 21. Milk yield was estimated by the suckling- weigh technique which measures the intake of kits after a fasting period (Mousa and Shetaewi, 1995; Abdel- Samee, 1997; Shetaewi et al., 2001). 
Table (1): Ingredients of the experimental diets used in the present study.

\begin{tabular}{|c|c|c|c|}
\hline \multirow{2}{*}{ Ingredients \% } & \multicolumn{3}{|c|}{ Experimental diets $^{1}$} \\
\hline & CON & $\begin{array}{l}\text { SGR } \\
\end{array}$ & TAR \\
\hline Yellow corn, $(8.8 \%)$. & 18 & 14.5 & 18 \\
\hline Wheat bran, (14.11\%). & 29.6 & 26.5 & 24.6 \\
\hline Soybean meal, (42.8 \%). & 15 & 16.6 & 15 \\
\hline Alfalfa hay, $\quad(14.25 \%)$. & 32 & 27 & 27 \\
\hline Molasses. & 3 & 3 & 3 \\
\hline Dicalcium P. & 0.35 & 0.35 & 0.35 \\
\hline Calcium carbonate (limestone) & 0.3 & 0.3 & 0.3 \\
\hline Sodium chloride (salt). & 1.05 & 1.05 & 1.05 \\
\hline Vitamins \& Mineral Premix * & 0.5 & 0.5 & 0.5 \\
\hline Antifungus & 0.1 & 0.1 & 0.1 \\
\hline Anticoccidiosis & 0.1 & 0.1 & 0.1 \\
\hline Test material $^{2}$ & 0 & 10 & 10 \\
\hline Total & 100 & 100 & 100 \\
\hline \multicolumn{4}{|c|}{$\begin{array}{l}\text { 1,2, Experimental diets } \mathrm{CON}=\text { Control, basal diet } a d \text { lib., } \mathrm{SGR}=10 \% \text { Sea grass, } \mathrm{TAR}=10 \% \text { Taro } \\
\text { haulms. }\end{array}$} \\
\hline \multicolumn{4}{|c|}{$\begin{array}{l}\text { * One kilogram of premix contain: Vit. A } 12000000 \mathrm{IU} \text {, Vit. } \mathrm{D}_{3} 220000 \mathrm{IU} \text {, Vit. E } 1000 \mathrm{mg} \text {, } \\
\text { Vit. K } 2000 \mathrm{mg} \text {, Vit. B } 1000 \mathrm{mg} \text {, Vit. B } 4000 \mathrm{mg} \text {, Vit. B }{ }_{6} 100 \mathrm{mg} \text {, Vit. B } \mathrm{B}_{12} 10 \mathrm{mg} \text {, } \\
\text { Pantothenic acid } 3.33 \mathrm{~g}, \text { Biotin } 33 \mathrm{mg} \text {, folic acid } 0.83 \mathrm{~g} \text {, Choline chloride } 200 \mathrm{~g}, \mathrm{Zn} 11.79 \mathrm{~g} \text {, } \\
\text { Mn } 5 \mathrm{~g}, \mathrm{Fe} 12.5 \mathrm{~g}, \mathrm{Cu} 0.5 \mathrm{~g}, \mathrm{I} 33.3 \mathrm{mg} \text {, Se } 16.6 \mathrm{mg} \text { and Mg } 66.7 \mathrm{~g} \text {. }\end{array}$} \\
\hline
\end{tabular}

Table (2): Chemical analysis (\%) of Sea-grass $(C$. nodosa), Taro haulms $(C$. esculanta) and the experimental diets of NZW rabbits.

\begin{tabular}{l|ccccccc}
\hline \multirow{2}{*}{\multicolumn{1}{c|}{ Items }} & \multicolumn{7}{c}{ \% On DM basis } \\
\cline { 2 - 8 } & DM & OM & CP & EE & CF & NFE & ASH \\
\hline $\begin{array}{l}\text { Sea-grass }(\boldsymbol{C} \text {. nodosa) } \\
\text { Taro haulms }\end{array}$ (C. & 89.2 & 70.29 & 8.41 & 0.99 & 10.12 & 50.77 & 29.71 \\
esculanta)* & 90.09 & 83.08 & 16.41 & 7.42 & 14.30 & 44.95 & 16.92 \\
\hline Chemical composition of experimental diets given to & NZW rabbits \\
\hline Diet (1): Control & 89.90 & 92.78 & 19.02 & 3.04 & 14.35 & 56.37 & 7.22 \\
Diet (2): SGR (10\%) & 89.70 & 90.48 & 19.15 & 2.79 & 13.51 & 55.03 & 9.52 \\
Diet (3): TAR (10\%) & 90.34 & 91.90 & 19.10 & 3.45 & 13.64 & 55.71 & 8.10 \\
\hline
\end{tabular}

Taro haulms (C. esculanta)*: Khayyal et al., (2017).

The does were removed from their kits nest at 08:00 on the morning. At 08:00 on the morning of the following day, the kits were weighed and allowed to suckle their dams. Kits body weights were then recorded. The difference in the weight of kits before and after suckling represents the amount of milk 


\section{EFFECT OF DIETS CONTAINING SEA-GRASS \& TARO HAULMS ON RABBITS 61}

produced by the dam. The total yield for the three weeks of lactation was thus estimated.

\section{Digestibility trials:}

Digestibility trials were designed to evaluate differences in digestibility values of different nutrients (CP, EE, CF, NFE, ASH, DM and OM) used throughout the experiments. Four digestibility trials were carried out to determine nutrient digestibility and the nutritive values of the experimental diets. Twelve male rabbits aged 13 months and weighed approximately $2.312 \pm 0.14 \mathrm{Kg}$ were chosen randomly from the three treatment groups (3/group). Rabbits were individually housed in metabolic cages $(40 \times 40 \times 50 \mathrm{~cm})$. Feces produced daily were collected in polyethylene bags and stored at $-20^{\circ} \mathrm{C}$ for five consecutive days. The experimental diets were offered daily for a primary period of $10 \mathrm{~d}$ and a collection period of $5 \mathrm{~d}$. Fresh water was provided all the time.

A tray covered with plastic sheet was put under each rabbit buck cage and feces that fell on that tray from the rabbit buck was collected every $24 \mathrm{~h}$ in the morning during the collection period following submission of the daily feed. Feces from each replicate were then cleaned from scattered feed and fur and dried in an electric oven at $65^{\circ} \mathrm{C}$ for $48 \mathrm{~h}, 105^{\circ} \mathrm{C}$ for $24 \mathrm{~h}$. Excreta of the five collection days were mixed together, weighed, finely grinded and stored in plastic bags. Samples of the feed and the excreta were used for chemical analysis to determine the digestibility coefficients. Diet samples and feces of all rabbit bucks were chemically analyzed for the determinations of percentages dry matter (DM), crude protein (CP), ether extract (EE), crude fiber (CF) and ash (AOAC, 2012).

Nutrient digestibility values of the experimental diets were estimated on DM basis. Values of total digestible nutrients (TDN) and digestible crude protein (DCP) were calculated according to the classic formula described by Cheek et al., (1982), as follows:

$$
\begin{gathered}
\mathrm{TDN} \%=\% \mathrm{DCP}+\% \mathrm{DCF}+\% \mathrm{DNFE}+2.25(\% \mathrm{DEE}) . \\
\% \mathrm{DCP}=\mathrm{DP} \times \% \mathrm{CP} / 100 .
\end{gathered}
$$

Where: $(\mathrm{DCP}=$ Digestible crude protein, $\mathrm{DCF}=$ Digestible crude fiber, $\mathrm{DNFE}=$ Digestible nitrogen free extract and $\mathrm{DEE}=$ Digestible ether extract).

\section{Statistical analyses:}

Data were analyzed by least - squares analysis of variance using the General linear model (GLM) procedure of SAS (2004) according to Steel and Torrie (1980).

Body weight of doe rabbits at different time periods (initial, breeding, kindling, post-kindling), feed intake during pregnancy and suckling time periods, milk yield through suckling weeks and through the three consecutive 
litters, live litter weight from birth to weaning and kits weights from the $1^{\text {st }} \mathrm{wk}$ to the end were analyzed by repeated measures analysis of variance (split-plot; Gill (1978). When a treatment $\chi$ time period interaction $(\mathrm{P} \leq 0.05)$ was detected for any trait, treatment effects within time were tested by one-way analysis of variance.

Data on litter weights at birth, weaning and weight of kits weaned per doe kindled were analyzed by one-way analysis of variance. Whenever $F$ value was significant means were compared using the least significant difference (LSD) test. Categorical data like kindling rate, litter size at birth and stillbirths were analyzed using Chi-Square tests. It tests the hypothesis that the distribution is the same across different groups (Steel and Torrie 1980).

\section{RESULTS AND DISCUSSION}

\section{Doe rabbit performance:}

\section{Body weight and fertility of doe rabbits:}

Results presented in Table (3) showed no significant differences (P > 0.05) among treatments in body weights at different time intervals of reproductive cycle of doe rabbits. Averages of the body weight at breeding time, body weight pre-kindling and body weight post-kindling were 2.898 , 3.200 , and $2.830 \mathrm{~kg}$, respectively. Means in the present study lies in the same range obtained by Ibrahim (2016) in NZW doe rabbits under similar conditions in North Sinai. These results presented in Table (3) show that percentage of does that gave birth/does bred (fertility) were generally high (83.3 to $91.7 \%$ ) compared with those obtained in earlier studies under similar conditions in North Sinai. For instance, Shetaewi (1998) found fertility ranged between 54.5 and $72.7 \%$ in Californian (CAL) and NZW doe rabbits and Shetaewi et al., (2000) found better values 78.6 to 85.7 in NZW but still lower than those obtained in the present study. Fertility did not differ significantly $(P>0.05)$ among treatments. However, values tended to be higher in the TAR group $(91.7 \%)$ followed by SGR $(87.5 \%)$ and CON $(83.3 \%)$ groups. The Taro haulms and Sea-grass contain substances or antioxidants that could enhance fertility. Millen et al., (2016) reported that Taro contains high levels of vitamin E. Moreover, SGR contain antioxidants like sulfated polysaccharide which has a role as antioxidants and has potential benefits towards fertility and spermatic parameters. It was able to protect rats testicular tissues against toxic substances Kolsi et al., (2018). Furthermore, Jeevitha et al., (2013) reported that SGR contains high amounts of vitamin A,

$\mathrm{C}$ and $\mathrm{E}$ in the rhizome/root. Shetaewi (1998) found that antioxidants like vitamin $\mathrm{E}$ improved $(\mathrm{P} \leq 0.05)$ fertility of NZW and CAL rabbits compared with the control (72.7 vs. 54.5). 
EFFECT OF DIETS CONTAINING SEA-GRASS \& TARO HAULMS ON RABBITS 63

Table (3): Effects of dietary treatments on weight changes of doe rabbits at different time periods of their reproductive cycle, and effects on their kindling percentages.

\begin{tabular}{|c|c|c|c|c|}
\hline \multirow{2}{*}{ Item } & \multicolumn{3}{|c|}{ Treatment $^{1,2,3}$} & \multirow{2}{*}{ S.E. ${ }^{4}$} \\
\hline & CON & SGR & TAR & \\
\hline BW at breeding time, $\mathrm{Kg} \ldots . . . .(1)$ & 2.920 & 2.89 & 2.881 & 0.066 \\
\hline BW pre- kindling time, $\mathrm{Kg}$.....(2) & 3.204 & 3.23 & 3.164 & 0.062 \\
\hline BW post-kindling, Kg & 2.867 & 2.83 & 2.790 & 0.060 \\
\hline No. does bred.....................(3) & 24 & 24 & 24 & \\
\hline No. does kindled. ................(4) & 20 & 21 & 22 & \\
\hline Kindling \% , or fertility (4) x 100/(3) & 83.3 & 87.5 & 91.7 & \\
\hline
\end{tabular}

Treatment, CON, Control, basal diet ad lib., SGR, 10\%. Sea-grass, TAR, 10\% Taro haulms

${ }^{2}$ Values are least-squares means. ${ }^{4}$ S.E. $=$ Largest standard error of the means.

${ }^{3}$ No significant differences were found between treatment means. $(P>0.05)$.

\section{Litter size and litter weight of doe rabbits:}

Litter size at birth (including stillbirths) did not differ significantly (P > $0.05)$ among treatments but tended to be higher in the SGR and TAR groups (7.52 and 7.32\%) compared with the control (6.8\%) (Table 4). Prolificacy i.e. no. of kits born alive/doe kindling differ significantly $(\mathrm{P} \leq 0.05)$ among treatments. Does fed on Sea-grass (SGR) and Taro haulms (TAR) gave more alive kits per doe kindling compared with those fed the control diet $(\mathrm{CON})$, 7.14, 7.09 and 6.15, respectively (Table 4). Prolificacy means obtained in the present study lies in the same range obtained by Shetaewi (1998) in NZW doe rabbits under similar conditions in North Sinai (6.17 to $7.25 \mathrm{~g}$ ) and higher than those obtained later (5.5 to $6.45 \mathrm{~g}$ ) in NZW Shetaewi et al., (2000). The increase in prolificacy may be due to the higher content of antioxidants like sulfated polysaccharide (Kolsi et al., 2018, vitamin E Millen et al., 2016) in SGR and TAR treatment groups.

Results of Table (4) also showed that kits livability at birth was higher $(\mathrm{P} \leq 0.05)$ and stillbirth was lower in the SGR and TAR groups as compared with the control.

Finally, dietary treatments increased $(\mathrm{P} \leq 0.05)$ total weight of kits born alive (litter birth weight alive) compared with the control, 359.7, 341.9 and $296.6 \pm 17 \mathrm{~g}$ for SGR, TAR and CON, respectively (Table 4). 
Table (4): Effects of dietary treatments on litter size, stillbirths and litter weight.

\begin{tabular}{l|l|ccc|c}
\hline \multirow{2}{*}{ Items } & \multicolumn{4}{c}{ Treatment $^{1,2}$} \\
\cline { 3 - 6 } & \multicolumn{1}{c}{ CON } & SGR & TAR & S.E. $^{3}$ \\
\hline \multirow{2}{*}{$\begin{array}{c}\text { Total of } \\
\text { Litter } \\
\text { Size }\end{array}$} & Total no. kits born. & 136 & 158 & 161 & \\
\cline { 2 - 6 } & No. kits born alive & 123 & 150 & 156 & \\
\cline { 2 - 6 } No. kits weaned. & 81 & 121 & 110 & \\
\hline \multirow{2}{*}{ Stillbirth } & $\begin{array}{l}\text { Stillbirths \% (no. kits born } \\
\text { deadx100/total no. kits born. }\end{array}$ & $9.56^{\mathrm{a}}$ & $5.06^{\mathrm{ab}}$ & $3.11^{\mathrm{b}}$ & \\
\hline \multirow{4}{*}{$\begin{array}{c}\text { Litter } \\
\text { Weight }\end{array}$} & D 1 (Birth), g. & $296.6^{\mathrm{b}}$ & $359.7^{\mathrm{a}}$ & $341.9^{\mathrm{a}}$ & 17 \\
\cline { 2 - 6 } & D 7, g. & $423.4^{\mathrm{b}}$ & $544.3^{\mathrm{a}}$ & $484.6^{\mathrm{ab}}$ & 32 \\
\cline { 2 - 6 } & D 14, g. & $669.9^{\mathrm{b}}$ & $929.1^{\mathrm{a}}$ & $824.8^{\mathrm{a}}$ & 62 \\
\cline { 2 - 6 } & D 21, g. & $1007.6^{\mathrm{b}}$ & $1347.2^{\mathrm{a}}$ & $1229.1^{\mathrm{a}}$ & 83 \\
\cline { 2 - 6 } & D 28 (Weaning), g. & $1439.0^{\mathrm{b}}$ & $1881.4^{\mathrm{a}}$ & $1760.2^{\mathrm{a}}$ & 123 \\
\hline
\end{tabular}

$\overline{\mathrm{a}, \mathrm{b}}$ Means in the same row with different superscripts differ $(\mathrm{P} \leq 0.05)$.

${ }^{1}$ Treatment, CON, Control, basal diet ad lib., SGR, 10\% Sea-grass, TAR, 10\% Taro haulms.

${ }^{2}$ Values are least-squares mean.

S.E. ${ }^{3}=$ Largest standard error of the means.

Higher means (553 - 557 g) were obtained earlier by Shetaewi (1998) in NZW and CAL doe rabbits in North Sinai and similar means by Shetaewi et al., (2000) in NZW (335 to $374 \mathrm{~g}$ ) under the same conditions. The increase in litter weight at birth due to feeding on Seagrass and Taro haulms may be attributed to the effect of the antioxidant or antimicrobial compounds found in these feeding stuffs. The C. nodosa and $C$. esculenta might have properties which could enhance livability of rabbit kits as reported by many workers. Abdel-Hady et al., (2007) found that the ethanolic extract of $C$. nodosa showed antimicrobial activities against all fungi and bacteria. Moreover, Pawar et al., (2018) stated that C. esculenta has antimicrobial, antihepatotoxic, and anti-lipid peroxidative properties.

Results presented in Table (4) show live litter weights of doe rabbits from birth to weaning as influenced by dietary treatments. A treatment $\mathrm{x}$ week interaction was detected $(\mathrm{P}<0.08)$, means were, therefore separated within weeks. As shown in the Table, significant differences between treatments were detected through all the weeks starting from birth to weaning. It is noted that means of SGR and TAR treatment groups were significantly higher $(\mathrm{P} \leq 0.05)$ than those of the control, whereas SGR and TAR did not differ $(\mathrm{P}>0.05)$. 
EFFECT OF DIETS CONTAINING SEA-GRASS \& TARO HAULMS ON RABBITS 65

\section{Milk yield of doe rabbits:}

Results presented in Table (5) showed that treatment means during the $1^{\text {st }}$ wk were almost similar. Means of daily milk yield were 87.6, 85.5 and $89.4 \mathrm{~g} / \mathrm{d}$ for CON, SGR, TAR treatment groups, respectively. Although feed intake (Table 7) of does during pregnancy was higher in SGR and TAR groups than the CON it was not reflected in increasing their milk yield during the $1^{\text {st }}$ wk of lactation. This could probably due to the method of estimating milk production of does (weighsuckle-weigh technique).

The kits during the $1^{\text {st }}$ wk postpartum are too young to completely empty their dams and took advantage of all their milk. During the $2^{\text {nd }}$ wk. the SGR group obtained the highest mean $(132.9 \mathrm{~g} / \mathrm{d})$ followed by the TAR group (127.2 $\mathrm{g} / \mathrm{d})$ and the CON group $(116.0 \mathrm{~g} / \mathrm{d})(\mathrm{P} \leq 0.10)$. Differences between the SGR and the CON groups reached significant level $(\mathrm{P} \leq 0.05)$ at the $3^{\text {rd }}$ wk $(165.4 \mathrm{vs}$. $137.2 \mathrm{~g} / \mathrm{d}$, respectively) whereas the TAR group was intermediate $(143.5 \mathrm{~g} / \mathrm{d})$. These results go on line with the significant increase $(\mathrm{P} \leq 0.05)$ in feed intake during lactation of rabbit does of SGR and TAR groups compared with the control (Table 7). It goes in line, too, with higher number of kits reared and weaned per doe kindling in the groups that were supplemented with sea-grass and taro haulms (Table 4). Kolsi et al., (2017) reported that Sea-grass $C$. nodosa could be utilized as a healthy food item for human consumption because it is rich in phenolic or antioxidant compounds.

Litter size or number of kits suckling could affect the amount of milk produced by the doe as mentioned by Lukefahr et al., (1983) and Mahmoud (2013). The SGR group had the highest number of kits per doe (5.9) followed by the TAR group (5.3), whereas the CON had the lowest number (5.04).

Total milk yield across treatments during the three weeks of lactation (Table 5) averaged $2.356 \mathrm{~kg}$. Treatment means in total milk yield did not differ $(\mathrm{P}>0.05)$. However, the SGR group tended to be higher $(2.407 \mathrm{~kg})$ followed by TAR group $(2.332 \mathrm{~kg})$ and the CON group $(2.315 \mathrm{~kg})$.

\section{Milk conversion ratio (MCR) of does:}

Results showed that the effect of week of lactation on MCR was not significant $(\mathrm{P}>0.05)$. The MCR was highest during the $1^{\text {st }}$ week (3.21) and decreased during the $2^{\text {nd }}(2.01)$ and the $3^{\text {rd }}(2.39)$ weeks. The effect of treatment on MCR was not significant ( $\mathrm{P}>0.05$ ), Table (6) showed that the overall means were $2.532,2.441$ and $2.620 \pm 0.14$ for CON, SGR and TAR, respectively. 
Table (5): Daily milk production (g) and total milk yield (kg/ $21 \mathrm{~d}$ ) of rabbit does throughout the different weeks of lactation as influenced by dietary treatments.

\begin{tabular}{|c|c|c|c|c|c|}
\hline \multicolumn{6}{|c|}{ Treatment $^{1,2,3}$} \\
\hline Items & Week & $\mathrm{CON}$ & SGR & TAR & Overall \\
\hline \multirow{3}{*}{$\begin{array}{c}\text { Daily milk } \\
\text { production } \\
\text { (g) }\end{array}$} & 1 & $87.6 \pm 6$ & $85.5 \pm 5$ & $89.4 \pm 5$ & $87.5 \pm 3$ \\
\hline & 2 & $116.0 \pm 8^{b}$ & $132.9 \pm 7^{a}$ & $127.2 \pm 7^{\text {ab }}$ & $126.0 \pm 4$ \\
\hline & 3 & $\begin{array}{c}137.2 \pm \\
10^{b}\end{array}$ & $165.4 \pm 9^{\mathrm{a}}$ & $143.5 \pm 9^{b}$ & $149.4 \pm 6$ \\
\hline \multicolumn{2}{|c|}{ Total milk yield (kg) } & $\begin{array}{l}2.315 \\
\pm .148 \\
(17)^{4}\end{array}$ & $\begin{array}{c}2.407 \\
\pm .117 \\
(21)\end{array}$ & $\begin{array}{c}2.332 \\
\pm .114 \\
(22)\end{array}$ & $\begin{array}{l}2.356 \\
\pm .01\end{array}$ \\
\hline
\end{tabular}

${ }^{\mathrm{a}, \mathrm{b}}$ Means in the same row with different superscripts differ $(\mathrm{P} \leq 0.05)$.

${ }^{1}$ Treatment, CON, Control, basal diet ad lib., SGR, 10\% sea-grass, TAR, 10\% Taro haulms

${ }^{2}$ Values are least-squares means \pm standard error

${ }^{3}$ No significant differences were found between treatment means. $(\mathrm{P}>0.05)$.

${ }^{4}$ No. of does kindled.

Table (6): Milk conversion rate of doe rabbits as influenced by dietary treatments.

\begin{tabular}{l|c|c|c|c}
\hline \multirow{2}{*}{\multicolumn{1}{c|}{ Items }} & \multicolumn{4}{c}{ Treatment $^{1,2,3}$} \\
\cline { 2 - 5 } & CON & SGR & TAR & S.E. $^{4}$ \\
\hline Milk Conversion Rate $(g / g)$ at & & & & \\
$1^{\text {st }}$ week & 3.228 & 2.963 & 3.435 & 0.23 \\
$2^{\text {nd }}$ week & 2.089 & 1.945 & 2.038 & 0.12 \\
$3^{\text {rd }}$ week & 2.205 & 2.507 & 2.438 & 0.15 \\
\hline Overall Means & $\mathbf{2 . 5 3 2}$ & $\mathbf{2 . 4 4 1}$ & $\mathbf{2 . 6 2 0}$ & $\mathbf{0 . 1 4}$ \\
\hline
\end{tabular}

${ }^{1}$ Treatment groups, $\mathrm{CON}=$ Control, basal diet ad lib., SGR=10\% Sea grass,

TAR $=10 \%$ Taro haulms. ${ }^{2}$ Values are least-squares means.

${ }^{3}$ No significant differences were found between treatment means ( $\left.P>0.10\right)$.

${ }^{4} \mathrm{SE}=$ standard error of least-square means.

*As milk intake of litter $(\mathrm{g})$ per litter weight gain $(\mathrm{g})$.

\section{Feed intake during pregnancy and lactation:}

Results presented in Table (7) show that feed intake of the SGR and TAR treatments was higher $(\mathrm{P} \leq 0.05)$ than that of the $\mathrm{CON}$ treatment during both pregnancy and lactation periods. 
EFFECT OF DIETS CONTAINING SEA-GRASS \& TARO HAULMS ON RABBITS 67

Table (7): Feed intake of doe rabbits during pregnancy and lactation periods of the first litter as influenced by dietary treatments.

\begin{tabular}{|c|c|c|c|c|c|}
\hline \multirow{2}{*}{$\begin{array}{l}\text { Feed intake } \\
\left(\text { g.hd }^{-1} \cdot d^{-1}\right)\end{array}$} & \multicolumn{3}{|c|}{ Treatment $^{1,2,3}$} & \multirow{2}{*}{ S.E. ${ }^{4}$} & \multirow{2}{*}{ OSL $^{5}$} \\
\hline & $\mathrm{CON}$ & SGR & TAR & & \\
\hline Pregnancy & $\begin{array}{c}\mathbf{1 3 8 . 9}^{\mathrm{b}} \\
(8)^{6}\end{array}$ & $\begin{array}{c}152.9^{\text {ab }} \\
(8)\end{array}$ & $\begin{array}{c}149.1^{\mathrm{a}} \\
(8)\end{array}$ & 5.6 & $<0.09$ \\
\hline Lactation & $\begin{array}{c}179.9^{b} \\
(8)\end{array}$ & $\begin{array}{c}235.1^{\mathrm{a}} \\
\text { (8) }\end{array}$ & $\begin{array}{c}216.1^{\mathrm{a}} \\
(8)\end{array}$ & 12.8 & $<0.05$ \\
\hline Overall & $\begin{array}{c}159.4^{b} \\
(16)\end{array}$ & $\begin{array}{c}194.0^{\mathrm{a}} \\
(16)\end{array}$ & $\begin{array}{c}182.6^{\mathrm{a}} \\
(16)\end{array}$ & 7.8 & $<0.05$ \\
\hline
\end{tabular}

${ }^{a, b}$ Means in the same row with different superscripts differ significantly.

${ }^{1}$ Treatment, CON, Control, basal diet ad lib., TAR, 10\% Taro haulms, SGR, 10\% sea-grass.

${ }^{2}$ Values are least-squares means. ${ }^{3} \mathrm{~A}$ treatment $\mathrm{x}$ litter interaction was detected $(\mathrm{P}<0.07)$.

${ }^{4}$ S.E. $=$ Largest standard error of the means. ${ }^{5} \mathrm{OSL}=$ Observed significance level.

${ }^{6}$ No. of does/treatment group.

The Sea-grass or Taro haulms could probably had improved the palatability of their diets. During pregnancy feed intake was increased by $10 \%$ and $7.1 \%$ in the SGR and TAR treatment groups compared with the control, respectively. This could be explained on the basis of the number of kits born alive per doe kindling in each treatment (Table 4). During pregnancy feed intake was greater in SGR and TAR treatments (152.9 and 149.1 g.hd ${ }^{-1} . \mathrm{d}^{-1}$, respectively) compared with the CON group (138.9 g.hd $\left.\mathrm{gd}^{-1} \cdot \mathrm{d}^{-1}\right)$.

During lactation, the same trend was noted but with greater increase i.e. by $30 \%$ and $20 \%$, respectively for SGR and TAR treatment groups when compared with the CON group. The greater demand of nutrients during lactation especially for multiparous animals like rabbits could justify these differences. The number of kits weaned per doe kindling was higher in SGR and TAR groups than the CON group (121, 110 and 81, respectively, (Table 4). Latu et al., (2017) stated that the nutrient requirements of doe rabbits.

\section{Digestibility coefficients and nutritive values:}

Results in Table (8) showed no significant differences ( $P>0.1)$ among treatments in digestion coefficients of DM, OM, CP, EE, CF and NFE.

In the same way, the nutritive values of SGR and TAR diets, in terms of total digestible nutrients (TDN), digestible crude protein (DCP) and digestible energy (DE) did not differ significantly among treatments. Feeding rabbits on TAR diet decreased the digestibility coefficients that might be due to the oxalate effect which is considered a major factor contributing to the anti- 
Table (8): Digestion coefficients (\%) and nutritive value (\%) of the experimental diets (LS means \pm SE):

\begin{tabular}{|c|c|c|c|c|}
\hline \multirow{2}{*}{ Item } & \multicolumn{4}{|c|}{ Experimental diet $^{1,2,3}$} \\
\hline & CON & SGR & TAR & $\pm \mathrm{SE}^{4}$ \\
\hline \multicolumn{5}{|c|}{ Digestion coefficients, \% } \\
\hline DM & 68.84 & 69.50 & 67.40 & 1.6 \\
\hline OM & 70.95 & 71.20 & 69.57 & 1.5 \\
\hline $\mathbf{C P}$ & 78.17 & 78.28 & 75.88 & 1.3 \\
\hline $\mathbf{E E}$ & 78.69 & 78.67 & 80.31 & 1.1 \\
\hline $\mathbf{C F}$ & 26.26 & 30.91 & 24.97 & 3.9 \\
\hline NFE & 79.48 & 78.21 & 78.41 & 1.1 \\
\hline \multicolumn{5}{|c|}{ Nutritive value (\%) } \\
\hline TDN & 69.48 & 67.13 & 67.80 & 1.3 \\
\hline DCP & 14.87 & 14.99 & 14.49 & 0.3 \\
\hline DE (Kcal/ Kg)* & 3052.047 & 2982.24 & 3005.54 & 60.0 \\
\hline
\end{tabular}

${ }^{\mathrm{T}}$ Treatment, CON, Control, basal diet ad lib., SGR, 10\% Sea-grass, TAR, 10\% Taro haulms

${ }^{2}$ Values are least-squares means.

${ }^{3}$ No significant differences were found between treatment means $(\mathrm{P}>.10)$.

${ }^{4}$ S.E. $=$ Largest standard error of the means.

$* \mathrm{DE}(\mathrm{Kcal} / \mathrm{Kg})=4.36-0.0491 \times \mathrm{NDF} \%$, Where, $\mathrm{NDF} \%=28.924+0.657 \times \mathrm{CF} \%$.

palatability effect of Taro waste (Agwunobi et al., 2002). It could be attributed also to the presence of anti-nutritional factors such as tannins, saponins, phytates and hydrocyanide in Taro waste (Abdulrashid and Agwunobi, 2009; Olajide et al., 2011).

Conclusively, the results of present work are promising and opened our eyes towards importance of carrying out further research in this direction in future using different levels of SGR or Tar with higher numbers of animals.

\section{REFERENCES}

Abdel-Hady, H. H.; Daboor, S. M. and Ghonemy, A. E. (2007). Nutritive and antimicrobial profiles of some seagrasses from Bardawil Lake, Egypt. Egyptian J. Aquatic Research. 33 (3):103 - 110.

Abdel-Samee, A. M. (1997). Responses of New Zealand White rabbits to thermal stress and its amelioration during winter and summer of North Sinai, Egypt. J. Arid Environ. 36: 333 - 342.

Abdulrashid, M. and Agwunobi, L. N. (2009). Taro cocoyam (Colocasia esculenta) meal as feed ingredient in poultry. Asian Network for Scientific Information. Pakistan J. Nutrition. 8 (5): 668 - 673. 
EFFECT OF DIETS CONTAINING SEA-GRASS \& TARO HAULMS ON RABBITS 69

Agwunobi, L. N.; Angwukan, P. O.; Cora, O. O. and Isika, M. A. (2002). Studies of the use of Colocasia esculenta (Taro cocoyam) in the diets of weaned pigs. Tropical Animal Health and Production, 34 (3): 241 - 247.

AOAC (2012). Official Methods of Analysis of AOAC International. $19^{\text {th }}$ Edition. Gaithersburg, MD (USA).

Cheek, P. R.; Patton, N. M. and Tempelton, G. S. (1982). Rabbit production. USA. $5^{\text {th }}$ Ed.

Gill, J. (1978). Design and analysis of experiments in the Animal and Medical Sciences. Vol (1). Iowa state Univ. Press, Ames.

Ibrahim, M. M. (2016). Effect of feeding some medicinal plants on reproductive performance of male and female rabbits under Sinai condition. Thesis Ph.D. Environ. Agric. Sci., Suez Canal Univ., Egypt.

Jeevitha, M.; Athiperumalsami, T. and Kumar, V. (2013). Dietary fiber, mineral, vitamin, amino acid and fatty acid content of seagrasses from Tuticorin Bay, Southeast coast of India., 90:135 - 146.

Khayyal, A. A.; Bakr, E. O. A.; Phillip, Y. L.; Hussein, A. M. and Khir, A. A. (2017). Effect of Diets Containing Dried Taro (Colocasia esculanta) Waste and Dried Yeast (Saccharomyces cerevisiae) on Performance of Growing Rabbits. J. Anim. and Poultry Prod., Mansoura Univ., 8 (6): 109 - 117.

Kolsi, R. B. A.; Salah, H. B.; Saidi, S. A.; Allouche, N.; Belghith, H. and Belghith, K. (2017). Evaluation of nutritional value, characteristics, functional properties of Cymodocea nodosa and its benefits on health diseases. Lipids Health Dis., 16 (1): 238.

Kolsi, R. B. A.; Allah, F. B. A.; Elleuch, M.; Kolsi, B.; El Feki, A. and Belghith, K. (2018). Antioxidant and fertility potentials of a marine sulfated polysaccharide potential antioxidant et de fertility d'un polysaccharide sulfate marine. J. I. M. Sfax, N., 28: 36 - 44.

Latu, M.; Olutunmogun, A. and Barie, P. (2017). Protein partitioning of pregnant and lactating rabbit does fed combination of concentrates and lablab hay. J. Anim. Prod. Res., 29 (1):1 93 - 199.

Lukefahr, S.; Hohenboken, W. D.; Cheeke, R. and Patton, N. M. (1983). Characterization of straight bred and crossbred rabbits for milk production and associative traits. J. Anim. Sci., 57: 1100 1107.

Mahmoud, E. A. A. (2013). A study on some factors affecting milk yield in New Zealand White rabbits under Egyptian conditions. Banha veterinary medical J., 25 (2): 13 - 22. 
Millen, B. E.; Abrams, S.; Campbell, L. A.; Anderson, C. A.; Brenna, J. T.; Campbell, W. W.; Clinton, S.; Hu, F.; Nelson, M.; Neuhouser, M. L.; Escamilla, R. B.; Siega-Riz, A. M.; Story, M. and Lichtenstein, A. H. (2016). The 2015 Dietary Guidelines Advisory Committee Scientific Report: Development and Major Conclusions. 7 (3): 438 - 444.

Mousa, M. T. and Shetaewi, M. M. (1995). Milk Yield of Chios-Ossimi Crossbred Ewes In Relation to the Yield of the Parental Breeds. Trop. Anim. Hlth Prod., 27: 50 - 54.

NRC (1977). National Research Council. Nutrient Requirements of Rabbits. Washington, DC. USA.

Olajide, R.; Akinsoyinu, A. O.; Babayemi, O. J.; Omojola, A. B.; Abu A. O. and Afolabi, K. D. (2011). Effect of processing on energy values, nutrient and anti-nutrient components of wild cocoyam (Colocasia esculenta (L.) Schott) corm. Pakistan Journal of Nutrition, 10 (1): 29 34.

Pawar, H. A.; Choudhary. P. D. and Kamat, S. R. (2018). An Overview of Traditionally Used Herb, Colocasia esculenta, as a Phytomedicine. Medicinal \& Aromatic Plants. (Los Angeles). 7 (4).

SAS, (2004). SAS Procedures Guide For Personal Computers, Statistical Analysis System Institute, Inc., Cary, N.C.

Shetaewi, M. M. (1998). Efficiency of dietary high levels of antioxidant vitamins $\mathrm{C}$ and $\mathrm{E}$ for rabbits subjected to crowding stress. Egyptian $J$. Rabbit Sci., 8 (2): 95 -112.

Shetaewi, M. M.; Hegazy, N. I. and Mousa, M. R. (2000). Influence of copper and corn oil supplementation on reproduction and growth of New-Zealand White rabbits in North Sinai. Mansoura Univ., J. Agric. Sci., 25(4): 1977 - 1990.

Shetaewi, M. M.; Abdel-Samee, A. M. and Bakr, E. A. (2001). Reproductive Performance and Milk Production of Damascus Goats Acacia Shrubs or Berseem Clover Hay in North Sinai, Egypt. Tropical Animal Health and Production. 33: 67 - 79.

Steel, R. G. D. and Torrie, J. H. (1980). Principles and Procedures of Statistics: A Biometrical Approach ( $2^{\text {nd }}$ Ed.). McGraw-Hill Book Co., New York.

Wadhwa, M. and Bakshi, M. P. S. (2013). Utilization of fruit and vegetable wastes as livestock feed and as substrates for generation of other valueadded products. RAP Publication, 04: 1 - 56. 
EFFECT OF DIETS CONTAINING SEA-GRASS \& TARO HAULMS ON RABBITS 71

تاثير علائق محتوية علي عثب البحر (Cymodocea nodosa) و

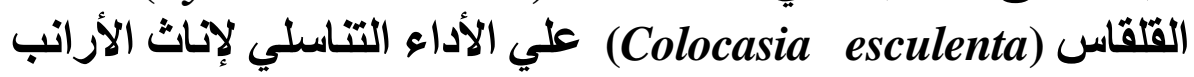
النيوزيلاندي تحت ظروف شمال سيناء

مسعد مسعد شتيوي - محمد رضا محمد موسي - السيد عثمان عبد النبي بكر -

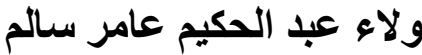
قسم الإنتاج الحيواني و الدواجن ، كلية العلوم الزر اعية البيئية ، جامعة العريش ، مصر

تم تقيم عدد 24 أنتي بالغة من الأرانب النيوزيلاندي الأبيض، تتر اوح أعمار هـا

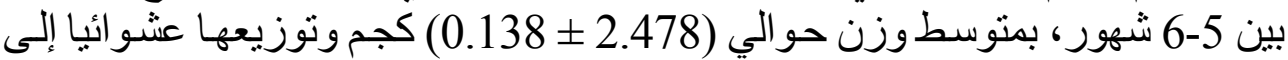

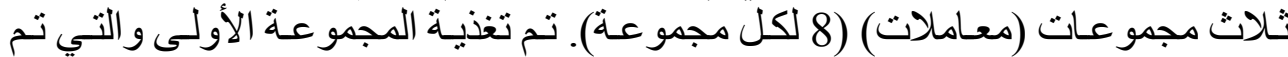

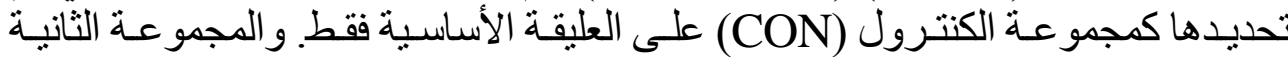

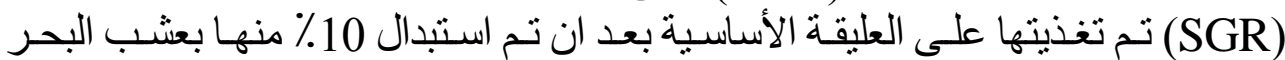

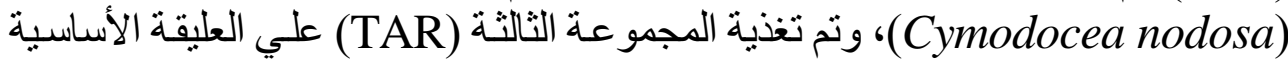
بعد استبدال 10٪ منهـا بعرش القلقاس (Colocasia esculenta).= و واستمرت التجربـة وقد أوضحت النتائج أن مجمو عة الأرانب التي كانت تتغذى علي عشب البحر أو أو أبن

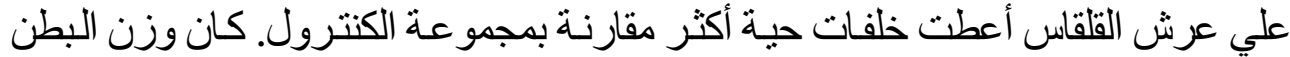

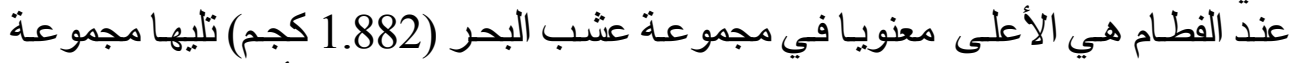

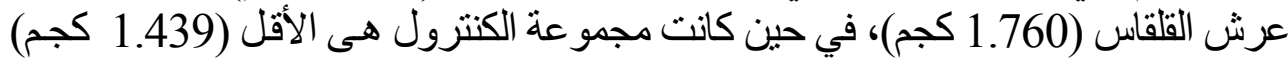

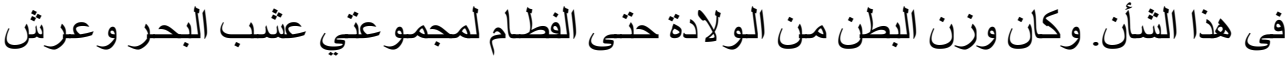

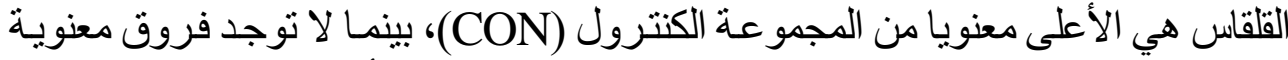

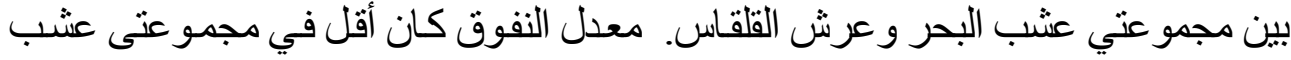

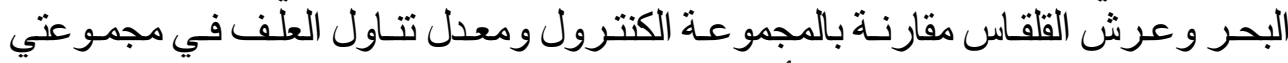

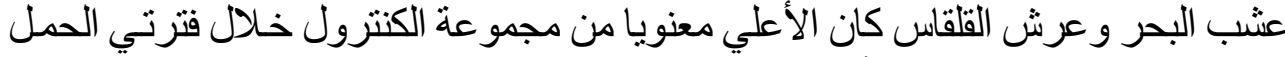

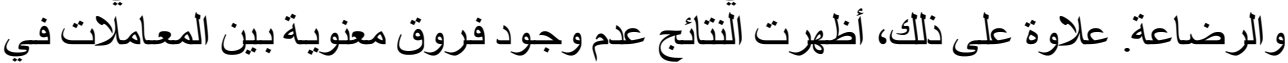

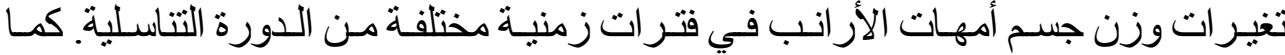

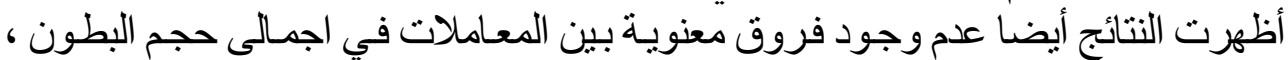

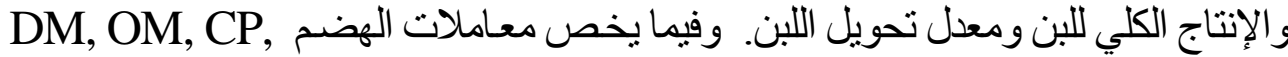
لم توجد فروق ذات دلالة إحصائية بين المعاملات.

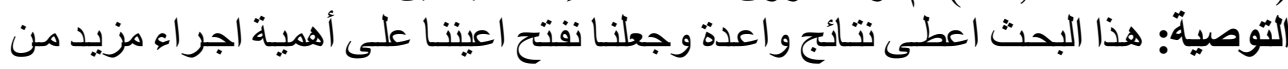

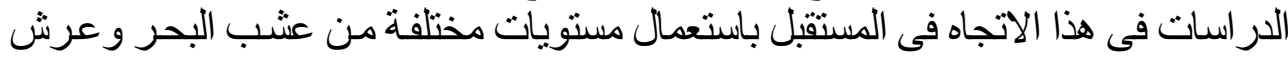
القلقاس على اعداد اكبر من الحيوانات. 